4 norden 



\section{Coexistence of genetically modified, conventional and organic crops in the Nordic countries}

Karina L. Vintersborg \& Svend Pedersen

TemaNord 2007:506 
Coexistence of genetically modified, conventional and organic crops in the Nordic countries

TemaNord 2007:506

(C) Nordic Council of Ministers, Copenhagen 2007

ISBN 978-92-893-1461-9

Copies: Print-on-Demand

This publication can be ordered on www.norden.org/order. Other Nordic publications are available at www.norden.org/publications

\section{Nordic Council of Ministers}

Store Strandstræde 18

DK-1255 Copenhagen K

Phone (+45) 33960200

Fax (+45) 33960202

www.norden.org

\section{Nordic Council}

Store Strandstræde 18

DK-1255 Copenhagen K

Phone (+45) 33960400

Fax (+45) 33111870

\section{Nordic cooperation}

Nordic cooperation is one of the world's most extensive forms of regional collaboration, involving Denmark, Finland, Iceland, Norway, Sweden, and three autonomous areas: the Faroe Islands, Greenland, and Åland.

Nordic cooperation has firm traditions in politics, the economy, and culture. It plays an important rol in European and international collaboration, and aims at creating a strong Nordic community in a strong Europe.

Nordic cooperation seeks to safeguard Nordic and regional interests and principles in the global community. Common Nordic values help the region solidify its position as one of the world's most innovative and competitive. 


\section{Content}

Preface

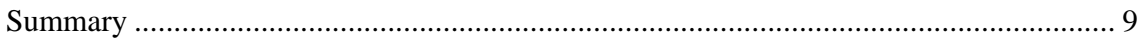

1. Facts about the agricultural structure in the Nordic countries .................................. 11

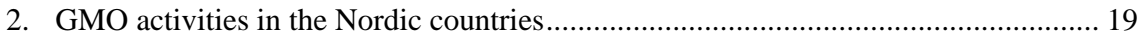

3. Status of the adoption of co-existence rules in the Nordic countries ........................... 21

4. Similarities and differences between co-existence rules in the Nordic countries ....... 27

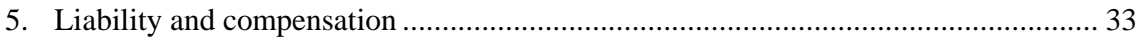

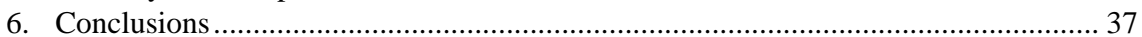

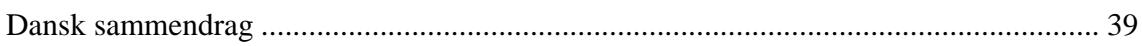

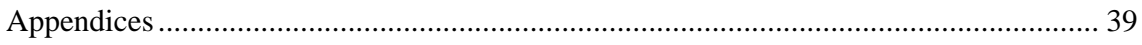





\section{Preface}

There is no common regulation of co-existence in the Nordic area. However in the Recommendation 16/2003 on GMO in Agriculture ${ }^{1}$ from the Nordic Council the Council recommends the Nordic Council of Ministers to initiate a Nordic cooperation on the investigation and development of possibly coordinated guidelines for co-existence of genetically modified (GM) crops with conventional and organic crops.

Even though geography, climate and agricultural traditions differ considerable in the region, the approach to the GMO issue in general among the Nordic countries is alike.

Co-existence in EU member states is also not covered by common legislation. However, according to Article 26a in Directive 2001/18/EC on the deliberate release into the environment of genetically modified organisms, the European Commission shall develop guidelines on the coexistence of genetically modified, conventional and organic crops.

Accordingly, the Recommendation on guidelines for the development of national strategies and best practices to ensure the coexistence of genetically modified crops with conventional and organic farming (2003/556/EC) was published by the Commission in 2003.

In the guidelines, coexistence is defined as "the ability of farmers to make a practical choice between conventional, organic and GM-crop production, in compliance with the legal obligations for labelling and/or purity standards."

In connection with the Danish chairmanship of the Nordic Council of Ministers in 2005 the Danish Plant Directorate carried through a Nordic project on co-existence. The aim of the project has been to investigate if a common approach to co-existence in the Nordic countries is relevant.

The project was financed by the Nordic Council of Ministers and included two workshops on issues regarding cultivation of GM crops and a seminar on liability and compensation.

The two workshops and the seminar were attended by experts from the relevant authorities in Denmark, Finland, Iceland, Norway and Sweden, which are dealing with genetically modified organisms (GMOs). A list of participants is included in the annex.

Speakers at the seminar on liability and compensation in relation to co-existence were from the European Commission, Germany, The Netherlands, United Kingdom and Denmark. The experts from Germany and the Netherlands, in particular, were invited because the approach to solve

\footnotetext{
${ }^{1}$ Rekommandation 16/2003 om GMO i jordbruget (A 1330/miljø)
} 
the liability and compensation issues is quite different in these two countries.

The representative from the European Commission was informing on conflicts between national compensation schemes and general EUlegislation.

A representative from the Danish Insurance Association made a presentation on the current situation regarding insurance against economic damage as a result of GMO admixture.

Links to the presentations can be found in the annex to the report.

The workshops were held in Copenhagen in June 2005 and March 2006, the seminar in October 2005. The aim was to discuss co-existence issues and to exchange experiences from each Nordic country. The meetings have been very valuable for all participants. Also the impact of getting to know each other is very much appreciated and of great importance for the future work in the Nordic countries and in the EU.

When the project started there was an expectation that most of the Nordic countries would finalise draft coexistence legislation within the time frame of the project. As this has shown up not to be the case, the present report only gives a picture of the situation at the time of writing the report. 


\section{Summary}

This report describes the status of adoption or preparation of regulation of coexistence between genetically modified (GM), conventional and organic crops in the Nordic countries by the end of 2006.

Chapter 1 gives an overview of the agricultural structure in the individual Nordic countries. There are large variations in the size of the cultivated area per farm between the countries. In addition, the relative distribution of crop types varies. So it is evident, that differences in agricultural structure between the Nordic countries may give rise to different ways of handling coexistence.

An overview of the activities related to the development of GM plants in the Nordic countries is given in Chapter 2. Also here differences can be found between the Nordic countries, both in the number of GM plants developed in the countries and in the number of experimental releases carried out. Several GM-plants have been experimentally released in Denmark, Finland and Sweden, whereas only barley has been released in Iceland and a greenhouse release of European aspen has been carried out in Norway.

The development of coexistence regulations is not exactly synchronous in the Nordic countries. As described in Chapter 3, at the time of writing this report, Denmark was the only country that had coexistence rules in place. In the other countries, coexistence legislation was in various stages of drafting and adoption, with Sweden being at the most advanced stage.

Similarities and differences between co-existence rules are described in Chapter 4. The main elements included in the co-existence rules or draft regulations in the Nordic countries seem to be quite similar. However the scope of the rules and their coverage of adhering industries may differ. Also, the crop specific measures decided or considered in each country seem to differ. As coexistence regulations are not yet ready in all the Nordic countries, the final outcome is still uncertain.

A specific coexistence issue is liability and compensation, which is dealt with in Chapter 5. Liability is dealing with the question of who is responsible for presence of GM material in conventional or organic crops close to the GM field. Compensation covers payment to a neighbouring farmer who suffers economic loss due to GM admixture in her conventional or organic crop. Some countries choose to establish a specific fund to pay compensation to neighbouring framers who experience decreased payment because of GMO presence in their harvest whereas others choose to settle such situations in court. 
Denmark has chosen to start up with a compensation scheme whereas the other countries were still considering which solution to choose at the time of writing the report.

Even though there is no real synchronization in the development of coexistence rules in the Nordic countries it was found to be of great value to exchange ideas and receive information as to how other countries try to solve this issue.

At the end of 2007 or beginning of 2008 it may be expected that at least Denmark, Sweden, Norway and Finland all have coexistence rules in place. By that time the first GM crop suited for cultivation in at least a couple of the Nordic countries might have been approved for cultivation in the European Union. 


\section{Facts about the agricultural structure in the Nordic countries}

Geography, geology and climatic conditions in the Nordic countries are very different. The distance from the most Northern part of Norway to the Southern part of Denmark corresponds to the distance from Denmark to the Southern part of Italy.

A map on the extent of the growing season in the Nordic countries is shown in Figure 1. It is evident that there are large differences in the length of the growing season within the geographic area consisting of the Nordic countries. Accordingly, differences in agricultural structure are almost inevitable.

The average farm size and the relative size of organic crop area in the Nordic countries are listed in Table 1.

Table 1. Average size of farms and relative size of organic crop area in the Nordic countries.

\begin{tabular}{llllll}
\hline & Denmark & Finland & Iceland & Norway & Sweden \\
\hline Average farm size & 54 ha & 31 ha & $>100$ ha & 20 ha & 48 ha \\
$\begin{array}{l}\text { Relative size of } \\
\text { organic crop area }\end{array}$ & $6 \%$ & $7.6 \%$ & $<2 \%$ & $4.2 \%$ & $\begin{array}{l}17 \% \text { (mostly } \\
\text { lay) }\end{array}$ \\
\hline
\end{tabular}

Information on the agricultural area and cultivated crops, etc., in each of the Nordic countries is given below. 


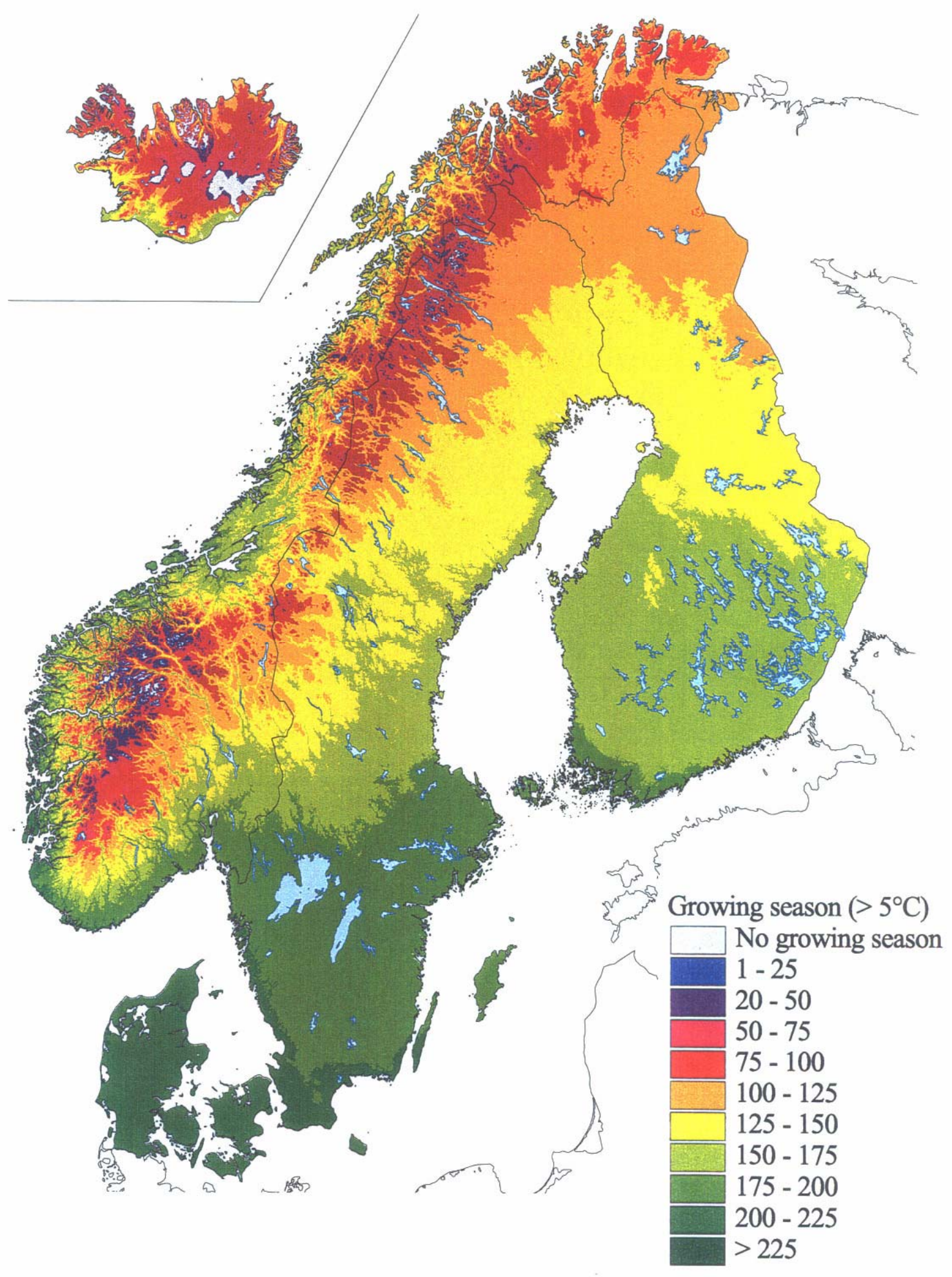

Figure 1. Growing season in the Nordic countries in number of days. 


\section{Denmark}

In Denmark the main crops cultivated are cereals (mainly wheat and barley), grasses and clover, maize, oilseed rape, seed production, sugar and fodder beets, potato, pulses and horticultural products.

The area of the main crops (in 1,000 ha) and their relative distribution in 2005 was:

Cereals (mainly wheat and barley)

Grasses and clover

Maize

Oilseed rape

Seed production

Sugar and fodder beets

Potato

Pulses

Horticultural products

$\begin{array}{rr}1,454 \text { ha } & 56 \% \\ 421 \text { ha } & 16 \% \\ 124 \text { ha } & 5 \% \\ 110 \text { ha } & 4 \% \\ 94 \text { ha } & 4 \% \\ 51 \text { ha } & 2 \% \\ 40 \text { ha } & 2 \% \\ 15 \text { ha } & 1 \% \\ 20 \text { ha } & 1 \%\end{array}$

The average farm size in Denmark was 53.6 ha for all farms and 50 ha for organic farms in 2005.

The size of the organic crop acreage in comparison with the total agricultural acreage was $6 \%$.

For some crops there are regional differences in crop types. They are:

- Oilseed rape: Mainly in the eastern parts of the country.

- Maize: Mainly in the western parts of the country.

- Sugar beet: Mainly in the south/eastern parts of the country.

- Potato: Mainly in the western parts of the country.

- Grasses and clover: Mainly in the western parts of the country.

Some of the crops have wild relatives. They are:

- Oilseed rape: Wild turnip (Brassica rapa ssp. campestris), brown mustard (B. juncea)

- Sugar and fodder beet: Sea beet (Beta vulgaris ssp. maritima)

- Grasses: Several species 


\section{Finland}

In Finland the following crops are cultivated:

Barley, oats, wheat, rye, sugar beet, potato, turnip rape, oilseed rape, pea, timothy, meadow fescue, red clover, strawberry, raspberry, apple, plum, lettuce and carrot (other plants are only produced in quite small areas). Greenhouse plants or forest trees are not listed.

The main agricultural area is Southern Finland (up to Vasa or Jyväskylä, or somewhat more North along the west coast). Barley grows all over Finland, and potato as well. Oilseed rape is only growing at the Southern coast, and hence turnip rape is the main oilseed crop.

Finland is the northernmost agricultural country in the world, and the agricultural area is situated to the North of the bulk of Swedish agricultural area. Due to the short summer, only a few varieties from Sweden and almost none from Denmark are applicable in Finland. Therefore, a large part of the varieties have been specially bred for the Finnish conditions.

\begin{tabular}{|c|c|c|}
\hline \multicolumn{3}{|c|}{ Agricultural production area in Finland (2003) } \\
\hline \multirow[t]{2}{*}{ Crop } & Area & \\
\hline & {$[1,000 \mathrm{ha}]$} & [\%] \\
\hline Barley & 530,0 & 24,1 \\
\hline Oats & 424,5 & 19,3 \\
\hline Silage $^{1}$ & 415,0 & 18,8 \\
\hline Pasture $^{1}$ & 102,2 & 4,6 \\
\hline Hay $^{1,2}$ & 101,2 & 4,6 \\
\hline Fallow & 220,4 & 10,0 \\
\hline Spring wheat & 156,8 & 7,1 \\
\hline Winter wheat & 34,4 & 1,6 \\
\hline Oilseeds & 74,6 & 3,4 \\
\hline Rye & 30,5 & 1,4 \\
\hline Cereal mixtures & 15,8 & 0,7 \\
\hline Sugar beet & 28,8 & 1,3 \\
\hline Potato & 28,7 & 1,3 \\
\hline Pea & 4,1 & 0,2 \\
\hline Other plants & 35,4 & 1,6 \\
\hline In total & $2,202,4$ & 100,0 \\
\hline${ }^{1}$ Forage crops in total & 618,4 & 28,1 \\
\hline
\end{tabular}


The average size of the Finnish farms is 31 hectares. 7.6\% (160,000 ha) of the field area is grown organically. The area is somewhat diminishing.

The distribution of organic production in Finland is presented below:

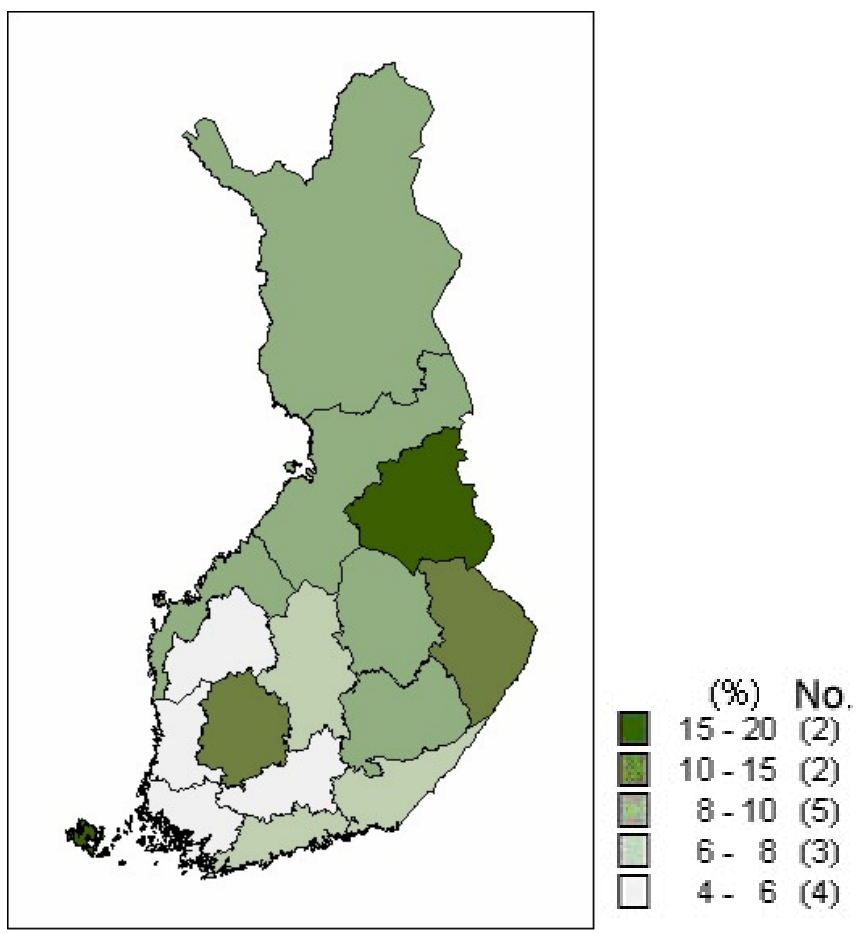

Figure 2. Share of organic farms in total arable area [\%] (KTTK 2004). Chart: Jukka Lahtinen 2005.

Some of the crops grown in Finland have ephemeral relatives. They are:

Barley (ephemeral, non-crossable, rare H. jubatum), oats (legally controlled weed with restricted crossing, A. fatua), sugar beet (some weed beet), potato (non-crossable Solanum), turnip rape (wild form), oilseed rape (wild turnip rape, Raphanus sp., Sinapis sp.; chromosomal differences), timothy (wild form), meadow fescue (wild form), red clover (wild form), raspberry (wild form), red currant (wild form) and apple (wild form). 


\section{Iceland}

- Grasses, potatoes, rape and barley are cultivated in Iceland.

- The area distribution of the crops relative to the total agricultural area is $2-3 \%$.

- The typical field sizes of the crops are $<5$ ha.

- The average farm size in Iceland is 100 ha+.

- The size of the organic crop acreage relative to the total agricultural acreage is $<2 \%$.

- In Iceland there are no regional differences in crop types.

- Rape is the only crop in Icelandic agriculture that has wild relatives.

\section{Norway}

In Norway the total agricultural area for those who applied for agricultural production subsidies was 1.04 million ha in 2005 of which 850,000 ha were fully cultivated. The fully cultivated area has decreased by 22,557 ha in the course of the last five years. The grain area was about 330,000 ha, corresponding to $32 \%$ of the total agricultural area.

Barley represented $50 \%$ of the total grain area, while wheat represented $26 \%$ and oat $23 \%$. A total of 16,212 holdings grew grain and oil seeds in 2005, and the average holding with grain and oil seeds grew 20.2 ha of the corresponding crops this year.

The area of meadows for mowing and pastures covered 645,000 ha in 2005 , corresponding to $63 \%$ of the total agricultural area. Three fourth of this area is fully cultivated land.

Agricultural area in use, total (in 1,000 ha)

Grain

Wheat

Rye

Barley

Oats

Oil seeds

Potato

Roots for feed, crops for green fodder and silage

Vegetables, field grown

Other crops

Meadows for mowing and pastures

Cultivated

Permanent grassland and surface cultivated land 
For grain and oil seeds production the number of holdings are 16,212. The distribution is as follows:

$\begin{array}{ll}\text { Ha } & \text { Holdings } \\ \text { 0.1-4.9: } & 1,932 \\ \text { 5-9.9: } & 5,347 \\ \text { 10-19.9: } & 4,945 \\ \text { 20-39.9: } & 3,904 \\ \text { > 40: } & 1,884\end{array}$

(Source: Statistics Norway)

The average grain area per holding rose from 13 ha to 20.2 ha from 1995 to 2005 . About $4.2 \%$ of the total agricultural acreage is grown organic.

There are some regional differences in crop types in Norway. The total agricultural area in Norway is 1.04 million ha, around 3\% of the total land area. The grain production is mainly on the marine sediments in south eastern and middle parts of Norway. The grass production you find in the remaining areas.

All the grass species have wild relatives in Norway.

\section{Sweden}

In Sweden cereals, lay, rape/turnip rape, sugar beets, leguminous plants and potatoes are cultivated.

The area distribution of the crops (in comparison with the total agricultural area) in 2005 was as follows:

$\begin{array}{lrr}\text { Cereals } & 1,024,000 \text { ha } & 32 \% \\ \text { Lay } & 1,028,000 \text { ha } & 32 \% \\ \text { Rape/turnip rape } & 82,000 \text { ha } & 3 \% \\ \text { Sugar beets } & 49,000 \text { ha } & 2 \% \\ \text { Potatoes } & 30,000 \text { ha } & 1 \%\end{array}$

The average farm size in Sweden is 48 ha.

The size of the organic crop acreage in comparison with the total agricultural acreage is:

$\begin{array}{ll}\text { Totally } & 17 \% \text { (mostly lay) } \\ \text { Cereals } & 5 \% \\ \text { Potatoes } & 2.6 \% \\ \text { Rape/turnip rape } & 2.4 \% \\ \text { Sugar beets } & 0.7 \%\end{array}$


There are regional differences in crop types in Sweden. Sugar beets are only grown in the south of Sweden. Rape is grown in the southern and central parts. Cereals, potatoes and lay are grown all over the country.

Rape and sugar beet have wild relatives:

- Rape is sexually compatible with Brassica rapa ssp. sylvestris, Brassica juncea, Raphanus raphanistrum and Sinapsis arvensis.

- Sugar beet is sexually compatible with Beta vulgaris ssp. maritima. 


\section{GMO activities in the Nordic countries}

Table 2 gives an overview of the activities related to the development of GM plants in the Nordic countries until now. The table also shows which crops are included in the current or drafted co-existence rules. The table gives a hint as to which GM plants might be cultivated in each of the countries some time in the future.

Table 2. GM plant activities in each of the Nordic countries.

\begin{tabular}{|c|c|c|c|c|c|}
\hline & Denmark & Finland & Iceland & Norway & Sweden \\
\hline $\begin{array}{l}\text { GM-crops developed } \\
\text { in the country }\end{array}$ & $\begin{array}{l}\text { Fodder beet } \\
\text { Sugar beet } \\
\text { Thale cress } \\
\text { Ryegrass }\end{array}$ & $\begin{array}{l}\text { Potato } \\
\text { White birch }\end{array}$ & Barley & None & Potato \\
\hline $\begin{array}{l}\text { Experimental re- } \\
\text { leases of GM crops }\end{array}$ & $\begin{array}{l}\text { Fodder beet } \\
\text { Sugar beet } \\
\text { Maize } \\
\text { Oilseed rape } \\
\text { Potato } \\
\text { Thale cress } \\
\text { Ryegrass }\end{array}$ & $\begin{array}{l}\text { Barley } \\
\text { Broccoli } \\
\text { Cabbage } \\
\text { Cauliflower } \\
\text { Spring turnip rape } \\
\text { Norway spruce } \\
\text { Scotch pine } \\
\text { Silver birch } \\
\text { Oilseed rape } \\
\text { Potato } \\
\text { Sugar beet } \\
\text { Tobacco }\end{array}$ & Barley & European aspen $^{2}$ & $\begin{array}{l}\text { Apple } \\
\text { Pear } \\
\text { Flax } \\
\text { Hybrid aspen } \\
\text { Maize } \\
\text { Oilseed rape } \\
\text { Potato } \\
\text { Thale cress } \\
\text { Spring turnip rape } \\
\text { Sugar beet }\end{array}$ \\
\hline $\begin{array}{l}\text { GM-crops included } \\
\text { in co-existence rules }\end{array}$ & $\begin{array}{l}\text { All crops (general rules) } \\
\text { Maize, beet and potato } \\
\text { (specific rules) }\end{array}$ & In preparation & - & $\begin{array}{l}\text { Maize } \\
\text { Potato } \\
\text { Oilseed rape }\end{array}$ & $\begin{array}{l}\text { All crops (general rules) } \\
\text { Maize and potato (spe- } \\
\text { cific rules) }\end{array}$ \\
\hline
\end{tabular}

The first commercial cultivation of a GM crop in the Nordic Region is expected to be a GM potato with an altered starch content. The potato has been developed by the Swedish company Amylogene (which has since been taken over by BASF Plant Science). At the moment the GM potato is in the approval proces in EU. Cultivation is expected in 2007 at the earliest, or maybe in 2008.

\footnotetext{
${ }^{2}$ http://biotech.jrc.it/deliberate/NO.asp. The release took place in a greenhouse. Such releases are considered to be deliberate release according to Section 9 of the Norwegian Gene Technology Act.
} 



\section{Status of the adoption of co-existence rules in the Nordic countries}

Development of co-existence rules is a complex matter. It is a common understanding that the rules have to be based on sound scientific knowledge.

In Denmark, Finland, Norway and Sweden the process leading to coexistence legislation has therefore been initiated by publishing a scientific report on co-existence. In Iceland, however, the co-existence law preparation is not so far yet.

The scientific reports are used as a basic tool to get an overview of the distribution of cultivation areas for conventional and organic crops, gene flow research, possible tools to reduced dispersal of GM material and other issues. In some countries also liability and compensation issues are investigated.

At the time of writing the present report actual law preparation had come to different phases in the Nordic countries. Denmark has had a coexistence legislation in place since 2005. Iceland was in early beginning of the work. Norway and Sweden were in final processes of the law preparation phase and Finland was in the consideration process. The status within the countries is outlined below.

As the Danish rules on co-existence were the first among both the Nordic and EU countries these rules seem to have inspired both the Norwegian and Swedish rules.

\section{Denmark}

The work on establisment of Danish co-existence rules started in 2002. The Minister of Food, Agriculture and Fisheries initiated the work by establishing three groups of people who should contribute to the development of a Danish co-existence strategy. It was a group of scientific experts, a group of stakeholders and a group of officials. A scientific report on co-existence "Rapport fra udredningsgruppen vedrørende Sameksistens mellem genetisk modificerede, konventionelle og økologiske afgrøder" ${ }^{3}$ was published in 2003 by the expert group. The report 
contains suggestions on co-existence measures for each of the agricultural crops cultivated in Denmark.

The Danish strategy on co-existence was also issued in 2003.

A frame law ${ }^{4}$ on co-existence was adopted by the Danish Parliament in 2004. The law is dealing with both cultivation and liability and compensation. The law came into force in 2005 together with two executive orders. One on cultivation ${ }^{5}$ of GM crops and another dealing with compensation ${ }^{6}$ to neighbouring farmers in case of economic loss due to GMO admixture.

The whole law preparation process was followed by a group of stakeholders in an open dialogue in order to develop a law complex which could satisfy all interests.

Also guidelines for the stakeholders explaining the rules, and control instructions for inspectors, have been published.

An Internet site ${ }^{7}$ with a map of GM fields in Denmark has been established.

Denmark is now in the process of evaluating the co-existence regulation. It was a part of an agreement in the Danish Parliament when adopting the law that an evaluation should take place two year after the entering into force of the law. The evaluation is therefore to be completed in April 2007.

The focus of the evaluation will be whether new scientific knowledge should lead to changes in the current crop specific rules. In addition, at the time of writing the first report in 2003, the scientific experts were not able to suggest co-existence measures for hybrid oilseed rape seed production or for cultivation of grasses and clover.

\section{Finland}

An umbrella law dealing with cultivation etc. is under preparation. In general Commission guidelines are broadly followed in the proposed measures. It is expected that the law will be handed over to the Finnish Parliament in 2007. Detailed rules for each GM crop may be laid down afterwards in lower level statutes.

The co-existence regulation work in Finland is based on the scientific report "Enabling the coexistence of genetically modified crops and conventional and organic farming in Finland ${ }^{8}$ ", completed by the Expert

\footnotetext{
${ }^{3}$ Udredningsgruppens rapport

http://www.fvm.dk/files/Filer/Landbrug/Rapport\%20fra\%20udredningsgruppen\%20-\%20internetversion.pdf

${ }^{4}$ Lov nr. 436 af 9. juni 2004 om dyrkning m.v. af genetisk modificerede afgrøder

${ }^{5}$ Bekendtgørelse nr. 220 af 31. marts 2005 om dyrkning m.v. af genetisk modificerede afgrøder

${ }^{6}$ Bekendtgørelse nr. 1170 af 7. december 2005 om kompensation for tab på grund af visse forekomster af genetisk modificeret materiale.

${ }^{7}$ http://gmomark.pdir.dk/

${ }^{8}$ http://wwwb.mmm.fi/julkaisut/tyoryhmamuistiot/2005/Trm2005 9a.pdf
} 
Work Group on Coexistence in May 2005; and on the final report (in Finnish) completed by the Steering Work Group on Coexistence in December 2005. The reports were ordered by the Ministry of Agriculture and Forestry, which appointed the Work Groups in 2004 in order to investigate the biological, agronomical and legal foundation for coexistence measures in Finland. The purpose of the reports was to prepare recommendations for measures in order to enable co-existence in Finland.

In Finland very few of the ready-and-waiting GM crop varieties are adapted to cultivation due to the special natural conditions. Therefore there is no need to rush through with the law preparation work.

Rules regarding compensation may comprise a certain degree of compensation from the State and a contribution from farmers growing GM crops, depending i.a. on guilt. Details of the law are dealt with in a law preparing group.

\section{Iceland}

Preparation of co-existence rules has not started yet and there is no date for the beginning of the work. An advisory board on genetically modified organisms represented by several relevant authorities is however established. The board is working broadly with GMOs regarding notifications and enforcements of the general GMO act, education on GMO, and opinion on new regulations.

The need for co-existence regulation in Iceland is limited. However GM barley which can produce valuable proteins such as human growth factors are planned to be cultivated in the near future. Initially cultivation of GM-barley will be in greenhouses but may later also take place in the fields.

Compensation has not yet been considered.

\section{Norway}

The law preparation on co-existence in Norway was started in June 2004. The preparations cover development of a proposal for new regulation on cultivation of GM crops and consideration of the need for special rules in that regulation on liability and compensation in addition to Section 23 of the Act No. 38 of 2 April 1993 relating to the production and use of genetically modified organisms etc.

A draft regulation on co-existence is expected to be ready during the first half of 2007. Stakeholders and relevant authorities have been involved in the preparation of the new regulation during the whole process.

The regulation is based on a scientific report. In the autumn 2004 the Norwegian Food Safety Authority engaged a scientist to make a report on 
how co-existence between GM-plants and conventional and organic farming could work in Norway.

In order to get input from different research communities and a more broad involvement, the report was sent to the Norwegian Scientific Committee on Food Safety to get their assessment. The Committee has not yet given their opinion.

The question of the need for special rules and arrangements for liability and compensation is still under consideration.

Norway generally adheres to EU rules even where they are not directly implemented. In this case where no EU legislation will be established, the Norwegian approach to co-existence regulation is based on the Danish rules.

Norwegian farmer associations have recommended not to use GM crops, in line with the general public who don't see a role for these crops in Norwegian agriculture.

\section{Sweden}

Draft rules on cultivation of GM-crops have been sent from the National Board of Agriculture after a review process to the Swedish Government in December 2005. The proposal was processed in the Government during 2006, but after the new Government came in place October 2006 some structural changes has been proposed. There is proposed a Governmental ordinance setting a framework for a detailed regulation from the National Board for Agriculture on crop specific and other necessary measures for a effective coexistence. The ordinance has been notified to the Commission in December 2006.

A report was ordered by the Swedish Government in 2002 in order to have a baseline on which a strategy on co-existence could be established ("Samexsistens i fält mellan genetiskt modifierade, konventionella och ekologiska grödor - en redovisning av förutsättningar”). Within the preparations for the report on the draft rules on co-existence rules a scientific assessment was made over GM-cultivation and actual results on e.g. gene flow.

A Committee of Inquiry started its work on liability in April 2006. It will investigate whether existing law covers the issue or new legislation or procedures are needed. The report shall be finished no later than 15 June 2007. Eventually new legislation on liability is expected to be in place in January 2008.

The co-existence legislation in Sweden is to a certain extent inspired by the Danish rules. 
Table 3. Overview of the status of adoption of co-existence rules and compensation schemes in the Nordic countries. The information is of November 2006.

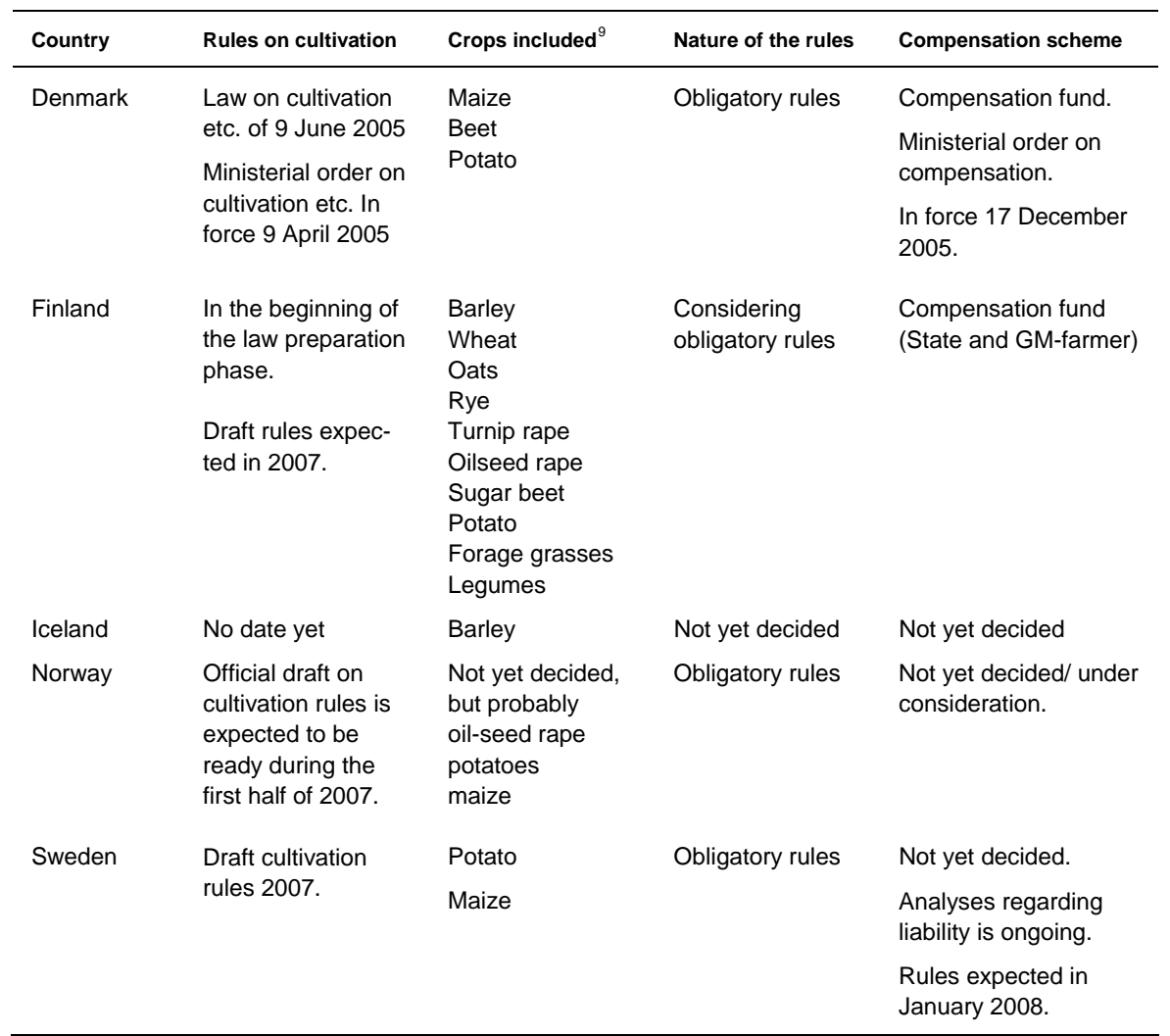

${ }^{9}$ Crops included at the moment. Other crops can be added to the list. 



\section{Similarities and differences between co-existence rules in the Nordic countries}

According to the coexistence guidelines issued by the European Commission it is the farmer introducing a production type new to the area in question - be it GM or organic crops - that is responsible of implementing the farm management measures necessary to limit gene flow.

However, at least Denmark, Sweden and Norway operate with the concept that the farmer introducing GM crops is responsible for assuring co-existence with conventional and organic farming.

This approach is securing that consumers will still be able to choose freely between GM, conventional and organic products.

The main elements included in the co-existence rules or draft regulations in the Nordic countries are quite similar. However the scope of the rules and their coverage of adhering industries are different. As coexistence regulations are not yet ready in all the Nordic countries, the final outcome of the rules is still uncertain. The following comparison is therefore based on the rules and draft rules available at the time of the writing of this report. At the moment only Denmark has a co-existence regulation in place.

\section{Common elements}

The actual common elements in the co-existence regulation in Denmark, Finland, Norway and Sweden are limited to certain information obligations. Both information to neighbours close to the GM field and information to the authorities about the location of GM fields are common elements.

Public information of GM fields is a common element in the Danish, the draft Norwegian and probably also in the Finnish regulation. As the information to the Swedish competent authority is obligatory and this information is official, it will be available for the Public.

Both the draft Swedish but especially the proposed Norwegian regulations are quite similar to the Danish rules. However, the Danish and Norwegian rules seem to be most detailed and similar while the proposed Swedish regulation is more superior. As mentioned earlier, however, there will be an ordinance (framework) allowing the National Board of Agriculture in Sweden to set a detailed regulation. 
Finland is in the early law preparation phase and concrete details are yet to be developed. The overall ideas are however information of neighbours within a certain distance to the GM fields as well as recording of GM cropping in a national register.

In Iceland the activities regarding cultivation of GM-crops is limited to cultivation of GM-barley under greenhouse conditions. Regulation on co-existence issues are therefore not considered yet.

According to the Danish and probably also the Norwegian legislation information distances are specific for each GM crop. This is also the intention in Finland. The draft Swedish rules have suggested a fixed information distance on $100 \mathrm{~m}$ from the GM field for potato and maize.

Both Denmark, Sweden, Norway and most probably also Finland are operating with cultivation distances for GM crops. Cultivation distances will be specific for each GM crop. Like the information distances, cultivation distances are not identical between the Nordic countries - i.e., Denmark and Sweden - mainly because of different amounts of assumed GMO content in conventional seed. Cultivation and information distances proposed or in force are outlined in Table 4 below.

Table 4. Co-existence measures in the Nordic countries.

\begin{tabular}{|c|c|c|c|c|}
\hline Country & Crops included $^{10}$ & $\begin{array}{l}\text { Assumed max. GMO } \\
\text { content in seed }\end{array}$ & Cultivation distance & Information distance \\
\hline Denmark & $\begin{array}{l}\text { Maize } \\
\text { Beet } \\
\text { Potato }\end{array}$ & $\begin{array}{l}0.5 \% \\
0.5 \% \\
0.5 \%\end{array}$ & $\begin{array}{l}200 \mathrm{~m} \\
2,000 \mathrm{~m} \text { (to seed } \\
\text { crop) } \\
50 \mathrm{~m} \text { (production) } \\
20 \mathrm{~m}\end{array}$ & $\begin{array}{l}300 \mathrm{~m} \\
3,000 \mathrm{~m} \\
75 \mathrm{~m} \\
30 \mathrm{~m}\end{array}$ \\
\hline Finland & $\begin{array}{l}\text { Most relevant GM } \\
\text { crops }\end{array}$ & & Not yet decided & Not yet decided \\
\hline Iceland & Barley & & Not yet considered & Not yet considered \\
\hline Norway & $\begin{array}{l}\text { Not yet decided, } \\
\text { but probably } \\
\text { oil-seed rape } \\
\text { potatoes } \\
\text { maize }\end{array}$ & & Not yet decided & Not yet decided \\
\hline Sweden & $\begin{array}{l}\text { Potato } \\
\text { Maize }\end{array}$ & $\begin{array}{l}0.1 \% \\
0.2 \%\end{array}$ & $\begin{array}{l}2 \mathrm{~m} \text { (draft) } \\
50 \mathrm{~m} \text { (draft) }\end{array}$ & $\begin{array}{l}100 \mathrm{~m} \text { (draft) } \\
\text { (for both GM potato } \\
\text { and maize) }\end{array}$ \\
\hline
\end{tabular}

Also some crop specific measures such as cleaning of equipment when handling GM-crops is a common element in the regulations or rules considered in Denmark, Norway and Sweden. Rules regarding storage and transportation are also common elements.

Co-existence regulation in Denmark and most probably in Norway too also covers crop specific measures such as cultivation intervals, control of volunteer plants as well as payment of a fee per hectare of GM cropping. The rules also covers education programmes for GM farmers and handlers of GM seed and GM crops, e.g., drivers or machine pools, approval

\footnotetext{
${ }^{10}$ Crops included at the moment. Other crops can be added to the list.
} 
of GM farmers and of providers of education programmes, registration and reporting of GM seed sale and publication of GM cropping locations.

Most of the above mentioned measures also pertain to Finland. Some of the elements will also be included in the draft Swedish ordinance. Iceland has not decided on these issues yet.

In order to give a detailed overview of the contents of the rules all elements are listed in table 5 below.

Table 5. Elements included in the co-existence rules in the Nordic countries.

\begin{tabular}{|c|c|c|c|c|c|}
\hline & Denmark & Norway & Sweden & Finland & Iceland \\
\hline Scientific report published & 2003 & - & 2003 & 2005 & - \\
\hline $\begin{array}{l}\text { Status of regulation of cultiva- } \\
\text { tion }\end{array}$ & In force & Working on draft & $\begin{array}{l}\text { Draft for the } \\
\text { Government }\end{array}$ & $\begin{array}{l}\text { Under conside- } \\
\text { ration }\end{array}$ & $\begin{array}{c}\text { Law preparation } \\
\text { not started }\end{array}$ \\
\hline \multicolumn{6}{|l|}{ Farmer } \\
\hline Education of GM-farmer & $x$ & $x$ & Possibility & $?$ & $?$ \\
\hline Authorisation of GM-farmer & $x$ & $x$ & - & $?$ & $?$ \\
\hline \multirow{3}{*}{$\begin{array}{l}\text { Information: } \\
\text { - of neighbours to GM-fields } \\
\text { - when selling GM-machinery } \\
\text { - when selling GM-field }\end{array}$} & $\mathrm{x}$ & & $x$ & $\mathrm{x}$ & $?$ \\
\hline & $x$ & $x$ & - & $?$ & $?$ \\
\hline & $x$ & $x$ & $x$ & $?$ & $?$ \\
\hline Reporting of GM-field locations & $x$ & $x$ & $x$ & $\mathrm{x}$ & $?$ \\
\hline Fee for growing GM-crops & $x$ & Not yet decided & $\begin{array}{l}\text { For sampling } \\
\text { and control }\end{array}$ & For control & $?$ \\
\hline \multirow{5}{*}{$\begin{array}{l}\text { Cultivation measures: } \\
\text { - distances } \\
\text { - intervals } \\
\text { - control of volunteer plants } \\
\text { - cleaning of machinery } \\
\text { - transportation measures }\end{array}$} & $x$ & $x$ & $x$ & $x$ & $?$ \\
\hline & $x$ & $x$ & Not yet decided & $x$ & $?$ \\
\hline & $x$ & $x$ & $\mathrm{x}$ & $x$ & $?$ \\
\hline & $\mathrm{x}$ & $\mathrm{x}$ & $x$ & $x$ & $?$ \\
\hline & For certain crops & For certain crops & $x$ & $?$ & $?$ \\
\hline \multicolumn{6}{|l|}{ Seed companies } \\
\hline $\begin{array}{l}\text { Registration of GM seed suppli- } \\
\text { ers }\end{array}$ & $\mathrm{x}$ & $x$ & - & $?$ & $?$ \\
\hline Reporting of GM seed sold & $x$ & $x$ & - & $?$ & $?$ \\
\hline \multicolumn{6}{|l|}{ Handlers of GM seed and crops } \\
\hline Education of GM crop handlers & $x$ & $x$ & - & $?$ & $?$ \\
\hline \multicolumn{6}{|l|}{ Providers of education } \\
\hline $\begin{array}{l}\text { Authorisation of providers of } \\
\text { education }\end{array}$ & $\mathrm{x}$ & $x$ & - & $?$ & $?$ \\
\hline \multicolumn{6}{|l|}{ Others } \\
\hline Control & $x$ & $x$ & $\mathrm{x}$ & $\mathrm{x}$ & $?$ \\
\hline $\begin{array}{l}\text { Public information of location of } \\
\text { GM fields }\end{array}$ & $x$ & $x$ & $\begin{array}{c}\text { Not yet } \\
\text { considered }\end{array}$ & Probably & $?$ \\
\hline $\begin{array}{l}\text { Publication of results from } \\
\text { control }\end{array}$ & $x$ & $x$ & $\begin{array}{c}\text { Not yet } \\
\text { considered }\end{array}$ & $?$ & $?$ \\
\hline \multicolumn{6}{|c|}{ Liability and compensation to conventional and organic farmers } \\
\hline $\begin{array}{l}\text { Status of regulation of liability } \\
\text { and compensation }\end{array}$ & In force & Work ongoing & Work ongoing & $\begin{array}{c}\text { Under } \\
\text { consideration }\end{array}$ & $\begin{array}{l}\text { Law preparation } \\
\text { not started }\end{array}$ \\
\hline $\begin{array}{l}\text { GM-farmer liable for GM admix- } \\
\text { ture }\end{array}$ & $\begin{array}{l}\text { Not liable when } \\
\text { comply with the } \\
\text { rules }\end{array}$ & Work ongoing & Work ongoing & $\begin{array}{l}\text { Not liable when } \\
\text { comply with the } \\
\text { rules }\end{array}$ & $?$ \\
\hline $\begin{array}{l}\text { Compensation for economical } \\
\text { loss due to GM-admixture in } \\
\text { crop }\end{array}$ & $x^{11}$ & Work ongoing & $\begin{array}{c}\text { Work } \\
\text { ongoing }\end{array}$ & $\begin{array}{l}\text { Under consid- } \\
\text { eration }\end{array}$ & $?$ \\
\hline
\end{tabular}

${ }^{11}$ Compensation within 1.5 times the cultivation distance if GMmaterial is identical to GM crop. Also losses due to presence of GM seed in organic seed are compensated. 


\section{Differences}

The main elements in common in the Nordic coexistence legislations are information to neighbours and authorities. Differences are identified especially in regard to how detailed the regulations are.

The Danish and draft Norwegian coexistence legislations are fairly detailed. Besides education obligations of farmers and handlers of GM crops the rules also cover other industries such as seed companies selling GM seed, the machinery and transport sector as well as providers of education programmes for GM farmers and handlers.

Also some of the assumptions on which co-existence rules are based are different, e.g., thresholds for adventitious presence of GM seed in conventional seed, which in turn leads to different cultivation distances.

Sweden is working with maximum $0.2 \%$ content of GM seed in conventional maize seed while Denmark uses $0.5 \%$. This leads to cultivation distances of $50 \mathrm{~m}$ in Sweden and $200 \mathrm{~m}$ in Denmark.

The biggest differences are expected to be found on compensation issues.

Compensation issues are in an early discussion phase in Norway, Sweden and Finland. Iceland has not started yet and Denmark has a regulation on this already. It is assumed that the approach to these issues could be quite different.

Liability and compensation issues are dealt with in the next chapter. 


\section{Liability and compensation}

While the legislation on GM cultivation as such in the Nordic countries has similarities the picture might be more differentiated when talking about liability and compensation. This area is more complex and involves both legal and economic aspects and considerations.

Liability is dealing with the question of who is responsible for presence of GM material in conventional or organic crops close to the GM field. Compensation covers payment to a neighbouring farmer who suffers economic loss due to the presence of GM admixture in her conventional or organic crop. Though, there may be different approaches in the scope of, and grounds for compensation between the Nordic countries.

Several models for dealing with these matters have been discussed in the EU countries. Some issues to consider are: Should liability be strict or based on fault? Is a new law necessary or can existing civil laws be used? Who should pay for a loss caused by GM admixture?

At the seminar on liability and compensation different approaches chosen in various EU countries were presented. Some EU countries have chosen to establish a fund which will pay for economical losses experienced by conventional or organic farmers. In other countries liability and economic loss is dealt with under civil law. A few countries (Austria, Luxemburg) have chosen an insurance scheme. Several countries have not decided on the issue yet.

According to the expert from the European Commission the Commission does not have much possibility to influence on national liability provisions. It is therefore a matter of each country to decide how to handle this.

The insurance business is not ready to offer insurance to GM farmers as they do not know the risk of GM admixture yet. They are apparently waiting for experience to be gained on the matter.

Among the Nordic countries Norway, Finland and Sweden are discussing or considering these topics at the moment while Iceland has not yet started this process. In Denmark rules regarding liability and compensation came into force in 2005.

Regarding thresholds on GM admixture both Denmark, Finland, Sweden as EU member states and also Norway and Iceland are operating with the same threshold of $0.9 \%$ GMO in the crop, if the presence of GMO is adventious or technically unavoidable. This threshold of GMO content in 
food and feed was implemented in the EU legislation by Regulation $1829 / 2003 / \mathrm{EC}^{12}$.

\section{Denmark}

Prior to the Danish law on liability and compensation a report covering legal aspects was published. The report was completed by a group of legal experts. It is dealing with legal aspects of co-existence, including liability issues. In December 2005 the ministerial order on liability and compensation came into force.

This regulation establishes that GM farmers are only liable for dispersal of GM material if they do not comply with the rules. This means that if the GM farmer has observed all co-existence rules he will not be charged if a neighbouring farmer suffers an economic loss from presence of GM material in his crop.

Accord to these rules conventional and organic neighbouring farmers will be compensated for an economic loss due to presence of GM material in their crop according to the threshold of $0.9 \%$. Compensation is however only given if the field is within a certain distance of the GM field.

The compensation distance is 1.5 times the cultivation distance. The GM-material shall de identical on a DNA level to the neighbouring GM crop.

Besides this rule organic farmers are guaranteed compensation if they suffer a loss because of GM seed in the organic seed they have sown.

Compensation will be financed by a fund which GM farmers are paying to. The fee is 100 DKK (approximately13 Euro) per hectare he cultivates with GM crops.

It is expected that the compensation fund in the long run will be replaced by some kind of insurance model.

\section{Finland}

Finland has not yet started the concrete development of rules regarding liability and compensation. The setup will be drafted when a law preparation group has been established. At the moment the idea is that there will be some kind of compensation scheme. Compensation could be financed by GM farmers but with a certain degree of support from the State.

\footnotetext{
${ }^{12}$ Regulation (EC) No 1829/2003 of the European Parliament and of the Council of 22 September 2003 on genetically modified food and feed.
} 


\section{Norway}

Section 23 of the Act No. 38 of 2 April 1993 relating to the production and use of genetically modified organisms etc.) establishes a strict liability regime for damage, nuisance or loss through the deliberate or unintended release of genetically modified organisms into the environment. There are no specific provisions related to co-existence.

Whether and how this Section applies to economic damage resulting from GMO-presence in conventional or organic crops is currently under consideration. The outcome of this consideration may result in a conclusion that this Section is sufficient, draft changes to this Section or a draft regulation on liability and compensation for economic damage resulting from GMO-presence in conventional or organic crops.

The outcome is expected to be ready during the first half of 2007. Any draft changes or draft regulation will be discussed with a reference group of stakeholders and authorities. After this a public hearing will take place.

\section{Sweden}

In Sweden liability and compensation issues are dealt with in a Governmental Committee of Inquiry. The committee started its work in April 2006 and reporting of the results will take place 15 June 2007. Eventually, new legislation is expected to be in place from January 2008.

\section{Iceland}

Liability and compensation issues have not been considered yet in Iceland.

In order to get an overview of the liability and compensation models, please see Table 5 . 



\section{Conclusions}

A common approach in the Nordic countries to the coexistence issue was discussed during the meetings.

The Working Group noted that it might not be feasible for all the Nordic Countries to search for common principles or overall goals for coexistence legislation. The group could, though, using the Nordic Countries as examples, elaborate on how differences between countries in agricultural structures and national approaches to the GMO issue at large influence on which elements are included in co-existence legislation.

In the Nordic region differences in geography and climate give rise to very diverse cropping conditions. In addition, at the time the working group started its work Denmark already had its co-existence legislation in place. Since there is no real synchronization between the Nordic countries in the establishment of co-existence rules the development of coordinated guidelines for coexistence thus does not seem to be relevant at the moment.

However, the Nordic countries to some extent have the same approach to establishing co-existence rules. And to the extent the Danish rules have served as inspiration for establishing co-existence rules in the other Nordic countries this might lead to rules that more or less resemble each other.

The working group members had different point of views regarding the possibility for having some kind of trans-national legislation on coexistence. Some found that differences between countries, particularly between Northern and Southern European countries, were too large to make the idea of common legislation feasible. Others found that it was too early to discard this idea, and that it should be developed further. At least one could aim at having a common approach and some kind of minimum basic rules.

All members found that the meetings had shown it was very important to exchange ideas and information between the Nordic Countries, and that the Working Group was a good place to do this. 



\section{Dansk sammendrag}

Denne rapport beskriver status for vedtagelse eller forberedelse af lovgining om sameksistens mellem genetisk modificerede (GM), konventionelle og økologiske afgrøder i de nordiske lande ved udgangen af 2006.

Kapitel 1 viser en oversigt over landbrugsstrukturen i de enkelte nordiske lande. Der er stor variation mellem landene i størrelsen af det dyrkede areal pr. bedrift. Herudover varierer den relative fordeling af afgrødetyper. Sådet står klart, at forskelle i landbrugsstrukturen mellem de nordiske lande forårsager forskellige måder at håndtere sameksistens på.

Et overblik over de aktiviteter, som relaterer sig til udviklingen af GM-planter i de nordiske lande, er givet i Kapitel 2. Også her kan der findes forskelle mellem de nordiske lande, både i antallet af GMplanterne udviklet i landene og i antallet af udførte forsøgsudsætninger. Adskillige GM-planter har været forsøgsudsat i Danmark, Finland og Sverige. På Island har der derimod udelukkende været forsøgsudsat byg, og i Norge europæisk asp (i drivhus).

Udviklingen af sameksistensregler er ikke ligefrem synkron i de nordiske lande. Som beskrevet i Kapitel 3 var Danmark på tidspunktet for skrivningen af denne rapport det eneste land, som havde sameksistensregler på plads. I de øvrige lande var sameksistenslovgivning på forskellige stadier af udkast og vedtagelse, med Sverige som det land, der var længst fremme.

Forskelle og ligheder mellem sameksistensregler er beskrevet i Kapitel 4. De hovedelementer, som er med i enten eksisterende sameksistensregler eller regler i udkast i de nordiske lande ser ud til at svare nogenlunde til hinanden. Dog kan rækkevidden af reglerne samt deres dækning af tilhørende industrier være forskellige. Endvidere ser de afgrødespecifikke foranstaltninger, som er besluttet eller under overvejelse i de enkelte lande, ud til at være forskellige. Da sameksistensregler endnu ikke er færdige i alle de nordiske lande, er det endelige udfald endnu ikke afklaret.

Et særligt sameksistensemne er ansvar og kompensation, som behandles i Kapitel 5. Ansvar vedrører spørgsmålet om, hvem der kan drages til ansvar for tilstedeværelsen af GM-materiale i konventionelle eller økologiske afgrøder tæt på GM-marken. Kompensation omfatter erstatning til en nabolandmand, som lider økonomisk tab som følge af GM-iblanding i hendes konventionelle eller økologiske afgrøde. Noigle lande vælger at oprette en særlig fond til udbetaling af kompensation til nabolandmænd, som oplever nedsat afregning på grund af GMO-forekomst i deres høst, mens andre vælger at lade sådanne sager afgøre i retten. 
Danmark har valgt at starte op med en kompensationsordning, medens de øvrige lande på tidspunktet for skrivningen af rapporten stadig overvejede, hvilken løsning de skulle vælge.

På trods af, at der ikke er nogen reel synkronisering i udviklingen af sameksistensregler i de nordiske lande, blev det fundet at være af stor værdi at udveklse ideer og modtage oplysninger om, hvordan andre lande prøver at løse dette spørgsmål.

Hen imod slutningen af 2007 eller starten af 2008 vil det kunne forventes, at i hvert fald Danmark, Sverige, Norge og Finland alle har sameksistensregler på plads. Til den tid kan den første GM-afgrøde egnet til dyrkning i i hvert fald et par af de nordiske lande være blevet godkendt til dyrkning i EU. 


\section{Appendices}

1. List of working group participants

2. Danish and Swedish rules

3. List of participants at the seminar on liability and compensation

4. Links to speakers presentations at the seminar on liability and compensation

5. Links to co-existence related web sites in the Nordic countries 


\section{Appendix 1. List of working group participants}

Kerstin Leistad

Norwegian Food Safety Authority

P.O. Box 383

2381 Brumundal

NORWAY

Torgun Johnsen

Norwegian Food Safety Authority

P.O. Box 383

2381 Brumundal

NORWAY

Knut Nordviken

Norwegian Food Safety Authority

P.O. Box 383

2381 Brumundal

NORWAY

Beate Ekeberg

Ministry of the Environment

P.O.Box 8013 Dep

0030 Oslo

NORWAY

Stefan Källman

Ministry of Agriculture, Food and Consumer Affairs

Agriculture Division

SE-103 33 Stockholm

SWEDEN

Anna-Clara Sjöström

Jordbruksverket

SE-551 82 Jönköping

SWEDEN

Thorsteinn Tomasson

Ministry of Agriculture

Sölvhólsgötu 7

150 Reykjavík

ICELAND

Árni Bragason 
Nature Conservation Division

Environment and Food Agency

Suðurlandsbraut 24

108 Reykjavík

ICELAND

Jussi Tammisola, Finland

Ministry of Agriculture and Forestry

Food and Health Department

Unit for Plant Production and Animal Nutrition

P.O. Box 30

FIN-00023 GOVERNMENT

Helsinki

FINLAND

Gitte Silberg Poulsen

Landbrugs- og Bioteknologikontoret

Skov- og Naturstyrelsen

Haraldsgade 53

2100 København Ø

DENMARK

Svend Pedersen

Department of seed

Danish Plant Directorate

Skovbrynet 20

DK-2800 Kgs. Lyngby

DENMARK

Lars Landbo

Department of seed

Danish Plant Directorate

Skovbrynet 20

DK-2800 Kgs. Lyngby

DENMARK

Karina Vintersborg

Department of seed

Danish Plant Directorate

Skovbrynet 20

DK-2800 Kgs. Lyngby

DENMARK 


\section{Appendix 2.}

\section{Danish rules}

Law on cultivation of GM crops:

http://www.pdir.dk/Files/Filer/Tvaergaaende/Lovstof/Hoering/

Lov_436_090604.pdf

Ministerial order on cultivation of GM crops:

http://www.pdir.dk/Files/Filer/Tvaergaaende/Lovstof/

Bek_220_310305.pdf

Ministerial order on compensation:

http://www.pdir.dk/Files/Filer/Tvaergaaende/Lovstof/GMO/

Bek_1170_071205.pdf

\section{Swedish rules}

At the time of finalisation of the report, the draft Swedish coexistence regulation had just been notified to the European Commission. When finally adopted it can be found via this link:

http://www.riksdagen.se/webbnav/index.aspx?nid=3910 


\section{Appendix 3. List of participants at the seminar on liability and compensation}

Alexander Schäfer, Federal Ministry of Consumer Protection, Food and Agriculture, Germany

Andreas Gumbert, European Commission, DG Agriculture and Rural Development

Beate Ekeberg, Ministry of the Environment, Norway

Birthe Schubart, Plant Directorate, Denmark

Christina Törnstrand, Ministry of Agriculture, Food \& Consumer Affairs, Sweden

Conny Öhman, Swedish Board of Agriculture, Sweden

Gitte Silberg Poulsen, Forest and Nature Agency, Denmark

Jaap Satter, Ministry of Agriculture, Nature and Food Quality, The Netherlands

Kaarlo Kinnunen, ProAgria Association of Rural Advisory Centres, Finland

Karina Vintersborg, Plant Directorate, Denmark

Knut Nordviken, Food Safety Authority, Norway

Lars Hansen, Ministry of Food, Agriculture and Fisheries, Denmark

Lars Landbo, Plant Directorate, Denmark

Lene Westergaard, Forest and Nature Agency, Denmark

Marianne Smith, Ministry of Agriculture and Food, Norway

Mike Adcock, Sheffield Institute of Biotechnological Law and Ethics, United Kingdom

Pernille Balslev Eriksen, Plant Directorate, Denmark

Rikke Reumert Schaltz, Forest and Nature Agency, Denmark

Stefan Källman, Ministry of Agriculture, Food \& Consumer Affairs, Sweden

Svend Pedersen, Plant Directorate, Denmark

Thorstein Tomasson, Ministry of Agriculture, Iceland

Torgun Johnsen, Food Safety Authority, Norway

Vibeke Henriques, Insurance and Pensions, Denmark 


\section{Appendix 4. Links to speakers presentations at the seminar on liability and compensation}

Jaap Satter, Ministry of Agriculture, Nature and Food Quality, The Netherlands:

http://www.pdir.dk/Files/Filer/Virksomheder/Froe/Plantegenetik/

COEXNetherlands.pdf

Alexander Schäfer, Federal Ministry of Consumer Protection, Food and Agriculture, Germany:

http://www.pdir.dk/Files/Filer/Virksomheder/Froe/Plantegenetik/

COEXGermany.ppt

Svend Pedersen, Plant Directorate, Denmark:

http://www.pdir.dk/Files/Filer/Virksomheder/Froe/Plantegenetik/

COEXDenmark.ppt

Andreas Gumbert, European Commission, DG Agriculture and Rural Development:

http://www.pdir.dk/Files/Filer/Virksomheder/Froe/Plantegenetik/

COEXCommission.ppt

Mike Adcock, Sheffield Institute of Biotechnological Law and Ethics, United Kingdom:

http://www.pdir.dk/Files/Filer/Virksomheder/Froe/Plantegenetik/

COEXLiabilityAndRedress.ppt

Vibeke Henriques, Insurance and Pensions, Denmark:

http://www.pdir.dk/Files/Filer/Virksomheder/Froe/Plantegenetik/

COEXDanInsuranceAss.ppt 
Appendix 5. Links to co-existence related web sites in the Nordic countries

Sweden

http://www.sjv.se/amnesomraden/vaxtmiljovatten/gmo/

kommersiellanvandning/

$\underline{\text { samexistens.4.1f85a8610dbb8e0d718000909.html }}$

Finland

Mid-term coexistence report, 31 May 2005:

http://wwwb.mmm.fi/julkaisut/tyoryhmamuistiot/2005/Trm2005_9a.pdf

http://www.coextra.eu/country_reports/coexistence_FI.html

Denmark

Report from the Danish working Group on the Co-existence of Genetically Modified Crops with Conventional and Organic Crops (2003):

http://web.agrsci.dk/djfpublikation/djfpdf/djfm94.pdf 